\title{
Pembuatan Sabun Padat Transparan Berbasis Bahan Minyak Jarak (Castor Oil) Dengan Penambahan Bahan Aktif Ekstrak Teh Putih (Camellia sinensis)
}

\author{
Asri Widyasanti ${ }^{1}$, Dwiyan Nugraha ${ }^{2}$, Dadan Rohdiana ${ }^{3}$ \\ 1,2 Departemen Teknik Pertanian dan Biosistem, Fakultas Teknologi Industri Pertanian, Universitas \\ ${ }^{3}$ Pusat Penelitian Teh dan Kina, Gambung, Jawa Barat \\ Email: asriwidyasanti@gmail.com
}

\begin{abstract}
ABSTRAK
Ekstrak teh putih mengandung senyawa katekin yang tinggi. Kandungan tersebut dapat menghambat dan membunuh pertumbuhan bakteri Staphylococcus aureus. Penambahan ekstrak teh putih pada sabun padat transparan berbasis minyak jarak dapat menambah aktivitas antibakteri. Penelitian ini bertujuan mengetahui proses pembuatan sabun padat transpran, mengetahui formulasi penambahan ekstrak teh putih, mengetahui sabun terbaik analisis berdasarkan karakteristik fisiko-kimia, aktivitas antibakteri, dan organoleptik, serta kesesuaian sabun dengan SNI 06-3532-1994. Perlakuan konsentrasi ekstrak teh putih adalah $A=0 \%(b / v), B=0,5 \%(b / v), C=1,0 \%(b / v)$, dan $D=1,5 \%(b / v)$ dari 300 gram basis sabun. Pengujian sampel sabun meliputi sifat fisika-kimia, aktivitas antibakteri, dan organoleptik. Hasil sabun terbaik berdasarkan nilai pembobotan sifat fisika-kimia dan aktivitas antibakteri adalah sampel sabun penambahan ekstrak teh putih $1 \%$ b/v (C) mencapai 3,39. Nilai hasil analisis sampel perlakuan $C$ adalah kadar air dan zat menguap 24,48\%, jumlah asam lemak 1,13\%, kadar asam lemak bebas 0,21\%, kadar fraksi tak tersabunkan $0,94 \%$, nilai $\mathrm{pH} 10,67$, kekerasan 0,0037 mm/gram/detik, stabilitas busa 44,4\% dan diameter daya hambat $18,5 \mathrm{~mm}$. Hasil sabun terbaik berdasarkan nilai pembobotan organoleptik adalah sabun kontrol (A) mencapai 2,75 .
\end{abstract}

Kata kunci :Sabun Padat Transparan, Minyak Jarak, Ekstrak Teh Putih, Aktivitas Antibakteri, Sifat FisikoKimia

\begin{abstract}
White tea extract containinga lot of catechin substance. That contents can inhibiting growth and kill of the staphylococcus aureus bacteria. The addition of white tea extract at transparent solid soap based castor oil can increasing of activity antibacterial. This research aimed to known creation process of transparent solid soap, to known formulation on white tea extract addition, to known teh best soap based on characteristics analysis of physical-chemical, antibacterial activity, and organoleptic, and suitability soap on SNI 06-35321994. The white tea extracts concentration were treatment $A=0 \%(w / v), B=0,5 \%(w / v), C=1,0 \%(w / v)$ and $D=1,5 \%(w / v)$ from 300 gram soap base. Parameter observed were included physical-chemical properties, antibacterial activity, and organoleptic test. The best soap of this research based on the appraisal values of physical-chemical properties and antibacterial activity were the soap with $1 \% \mathrm{~b} / \mathrm{b}$ white tea extract added reached 3.39. The analysis results of those soap were $24.48 \%$ of water content and evaporating substances, $1.13 \%$ of total fatty acid, $0.21 \%$ of free fatty acid, $0.94 \%$ of unsaponified fraction, $\mathrm{pH}$ value of 10.67 , hardness $0.0037 \mathrm{~mm} / \mathrm{g} / \mathrm{sec}$, the foam stability of $44.4 \%$ and inhibition antibacterial diameter of $18.5 \mathrm{~mm}$. The best soap of this research based on the appraisal values of organoleptic was control (without white tea extract addition) soap reached 2.75 .
\end{abstract}

Keywords:Transparent Soap, Castor Oil, White Tea Extract, Antibacterial Activity, Physico-chemical Properties

\section{PENDAhULUAN}

Tanaman teh (Camellia sinensis) dikenal diseluruh penjuru dunia. Teh populer akan khasiat kandungannya yang begitu banyak dan bermanfaat bagi kehidupan manusia sehari-hari. Teh putih (white tea) merupakan teh yang didapat dari ujung daun teh yang masih belum mekar dan terdapat bulu - bulu kecil dilapisan luarnya. Berdasarkan pemanfaatan penggunaan pada suatu produk, teh terbagi kedalam 2 kategori yaitu produk pangan dan produk non pangan. Pada produk non pangan, salah satu sifat teh yang diambil manfaatnya adalah aktivitas antibakteri. Aktivitas antibakteri ini dapat menghambat pertumbuhan bakteri sehingga bisa dimanfaatkan untuk produk non pangan 
seperti sabun, kosmetik, dan sebagainya. Kemampuan aktivitas antibakteri ini terjadi karena kandungan senyawa pada teh yaitu polifenol dan katekin. Hilal dan Engelhardt (2007) menyatakan kandungan senyawa polifenol dan katekin pada teh putih memiliki presentase yang lebih tinggi dibandingkan teh hijau, sehingga membuat aktivitas antibakteri menjadi sangat kuat agar dapat menghambat pertumbuhan dan membunuh bakteri yang merugikan. Menurut Widyasanti (2014), memaparkan aktivitas antibakteri ekstrak teh putih terhadap bakteri gram positif dan negatif menunjukkan hasil positif dapat menghambat bakteri seperti Staphylococcus aureus dan Staphylococcus epidermis. Bakteri tersebut jika dibiarkan akan menyebabkan penyakit seperti bisul, jerawat, dan lainnya pada kulit. Teh putih memiliki potensi dijadikan bahan aktif tambahan dalam produk pembersih untuk meningkatkan daya bersih. Salah satu produk pembersih yang bisa dan cocok untuk diberikan penambahan ekstrak teh putih salah satunya adalah sabun padat.

Sabun padat merupakan salah satu produk industri kosmetik dan farmasi yang sering digunakan masyarak Indonesia dalam kehidupan sehari-hari untuk membersihkan bakteri/mikroba, kotoran yang menempel pada kulit tubuh manusia. Jika kulit tidak dibersihkan maka bakteri tersebut akan menjadi penyebab munculnya infeksi kulit dan penyakit lainnya. Masyarakat menyadari permasalahan tersebut sehingga menjadikan produk sabun menjadi salah satu kebutuhan yang penting disemua kalangan masyarakat. Data Badan Pusat Statistik dari tahun 2004 2009 mengenai data produksi, konsumsi, impor, dan ekspor sabun mengalami peningkatan yang signifikan. Konsumsi sabun pada tahun 2004 sebesar 55.832,930 ton dan terus meningkat hingga mencapai sebanyak $101.631,090$ ton pada tahun 2009 (BPS, 2009). Konsumsi masyarakat tehadap sabun memiliki kecenderungan meningkat setiap tahunnya. Produk sabun saat ini telah banyak jenisnya, menurut Hambali, dkk (2005) menerangkan jenis sabun berdasarkan bentuk terjadi kedam dua bentuk yaitu padat dan cair, sedangkan jenis sabun berdasarkan penampakannya terbagi kedalam 3 macam antara lain opaque, translucent, dan transparent. Sabun padat transparent ini memiliki karakteristik penampakan yang tembus cahaya dan bening (transparan) dibanding jenis sabun lain. Penampakan sabun yang transparan dihasilkan oleh penambahan bahan gliserin dan etanol dalam pembuatan. Karakteristik lain yang dimiliki sabun pada transparan dipengaruhi oleh bahan - bahan penyusun lainnya tanpa terkecuali minyak.

Minyak merupakan komposisi bahan utama dalam pembuatan sabun yang berperan dalam reaksi saponifikasi sabun dengan alkali $(\mathrm{NaOH})$. Minyak yang digunakan dalam penelitian ini adalah minyak jarak. Minyak jarak termasuk kategori superlatting oil. Minyak yang termasuk golongan ini memiliki nilai lebih dalam melembabkan dan melembutkan kulit tetapi tidak memiliki zat aktif yang mampu menghambat bakteri,sehingga ekstrak teh putih yang kaya polifenol perlu ditambahkan untuk memperbaiki sifat dari sabun.

Berdasarkan uraian diatas, maka suatu potensi sangat menjanjikan untuk membuat sabun padat transparan dengan penambahan bahan aktif esktrak teh putih berbasis minyak jarak untuk diproduksi massal. Namun ketidaktersediaan formulasi pembuatan sabun tersebut membuat masyarakat ragu-ragu. Maka dari itu, perlu dilakukan penelitian ini untuk mencari formulasi pembuatan sabun padat transparan dengan penambahan ekstrak teh putih berbasis minyak jarak sehingga menghasilkan produk akhir yang baik dan optimal.

\section{BAHAN DAN METODE}

Penelitian ini dilaksanakan pada bulan Agustus sampai dengan Mei 2016 bertempat di Universitas Padjadjaran Laboratorium Pasca Panen dan Teknologi Proses FTIP, Laboratorium Kimia FMIPA, Laboratorium Mikrobiologi Pangan FTIP, dan Laboratorium Produksi Ternak Potong Fakultas Peternakan.Alat yang digunakan pada penelitian ini meliputi Timbangan Analitik, Grinder, Tyler sieves, Oven, Gelas ukur, Beaker glass, Beaker glass, Kertas saring, Corong Buchner, Rotary vacuum evaporator, Botol kaca vial, Desikator, Piknometer, Tabung Reaksi, Cawan aluminium, Erlenmeyer, Batang pengaduk, Gunting, Hot plate stirrer, Waterbath, Termometer Couple, 
Pipet volume, Cetakan sabun silicon, Vortex, Kertas Lakmus, Penetrometer.

Bahan yang digunakan pada penelitian ini adalah teh putih yang berasal dari Pusat Penelitian Teh dan Kina (PPTK) Gambung -

\begin{tabular}{|c|c|c|c|c|c|}
\hline \multicolumn{6}{|c|}{ 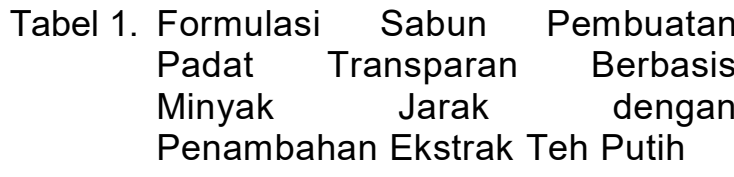 } \\
\hline \multirow{2}{*}{\multicolumn{2}{|c|}{ Bahan (g) }} & \multicolumn{4}{|c|}{$\begin{array}{c}\text { Perlakuan Penambahan } \\
\text { Ekstrak Teh Putih (g) }\end{array}$} \\
\hline & & $\begin{array}{l}\text { A } \\
(0 \%)\end{array}$ & $\begin{array}{l}B \\
(0,5 \% \\
)\end{array}$ & $\begin{array}{l}\mathrm{C} \\
(1 \%)\end{array}$ & $\begin{array}{l}D \\
(1,5 \%\end{array}$ \\
\hline \multicolumn{2}{|c|}{$\begin{array}{l}\text { Ekstrak Teh } \\
\text { Putih (b/v) }\end{array}$} & 0 & 1,5 & 3 & 4,5 \\
\hline \multicolumn{2}{|l|}{ Asam } & 30 & 30 & 30 & 30 \\
\hline \multicolumn{2}{|l|}{ Minyak } & 60 & 60 & 60 & 60 \\
\hline \multicolumn{2}{|c|}{$\mathrm{NaOH} 30 \%$} & 73,5 & 73, & 5 & 73 \\
\hline \multicolumn{2}{|l|}{$\mathrm{NaCl}$} & 1,5 & 1,5 & & 1,5 \\
\hline \multicolumn{2}{|c|}{ Etanol $96 \%$} & 45 & 45 & 4 & 45 \\
\hline \multicolumn{2}{|l|}{ Gliserin } & 39 & 39 & & 39 \\
\hline \multicolumn{2}{|c|}{ Gula Pasir } & 22,5 & 22,5 & 22,5 & 22,5 \\
\hline \multicolumn{2}{|c|}{ Coco - DEA } & 9 & 9 & 9 & 9 \\
\hline \multicolumn{2}{|c|}{ Aquadest } & 19,5 & 18 & 16,5 & 15 \\
\hline \multicolumn{2}{|c|}{ Fragrance } & 0,1 & 0,1 & 0,1 & 0,1 \\
\hline
\end{tabular}

Jawa Barat, minyak jarak, $\mathrm{NaOH}$ (Natrium Hidroksida) $30 \%$, gliserin, gula pasir, asam sitrat, coco-DEA (Dietanolamida), $\mathrm{NaCl}$ (Natrium Klorida), dan asam stearat, etanol $96 \%$, aquades.

Metode penelitian yang digunakan adalah metode penelitian eksperimental dengan analisa deskriptif. Penelitian ini dilakukan untuk menguji hipotesa dalam mencari hubungan, pengaruh, maupun perbedaan komposisi sabun padat transparan berbasis minyak jarak dengan penambahan ekstrak teh putih yang berbeda-beda.

Perlakuan yang dicari adalah konsentrasi ekstrak teh putih yang terbaik dalam formula pembuatan sabun padat transparan dari minyak jarak (castor oil). Konsentrasi ekstrak teh putih yang ditambahkan dalam pembuatan sabun padat transparan ini adalah $1,5 \%$ dengan volume penambahan 0 $\% \mathrm{~b} / \mathrm{v}, 0,5 \% \mathrm{~b} / \mathrm{v}, 1 \% \mathrm{~b} / \mathrm{v}$, dan $1,5 \% \mathrm{~b} / \mathrm{v}$ dari berat basis sabun $300 \mathrm{~g}$. Berikut penyajian komposisi formulasi sabun pembuatan sabun padat transparan berbasis minyak jarak dengan perlakuan penambahan ekstrak teh putih yang ditampilkan pada Tabel 1 .

\section{Prosedur Penelitian \\ Persiapan Bahan Peko Teh Putih}

Tahapan pertama dalam penelitian kali ini adalah mempersiapkan teh putih kering menjadi bubuk yang dilanjutkan untuk proses ekstraksi. Proses dalam tahapan ini adalah pengecilan ukuran (grinding) dan pengayakan.

\section{Pembuatan Ekstrak Teh Putih}

Bubuk teh putih diekstraksi dengan metodemaserasi. Bubuk teh putih yang lolosayakan 18 mesh sebanyak $100 \mathrm{~g}$ dimasukkankedalam beaker glass, kemudiandimaserasi dengan $900 \mathrm{ml}$ larutan etanol96\% (1:9 b/v) pada suhu kamar selama 24jam. Penyaringan dilakukan dengan menggunakankertas filter (Whatman paper no.40). Filtrat diuapkan menggunakan rotary vacuum evaporator dengan suhu $50^{\circ} \mathrm{Cselama} 2-3$ jan sampai diperoleh ekstrak cairankental.

\section{Pembuatan Sabun Padat Transparan Setiap Perlakuan}

Pembuatan sabun padat transparan dilakukan dengan hot process.Minyak jarak sebanyak $60 \mathrm{~g}$ pada beaker glass dipanaskan menggunakan water bath hingga suhu bahan mencapai $70{ }^{\circ} \mathrm{C}$, Asam stearat $30 \mathrm{~g}$ dicampurkan ke dalam beaker glasssambil diaduk hingga tercampur semua pada suhu bahan $70^{\circ} \mathrm{C}-80^{\circ} \mathrm{C}, \mathrm{NaOH} 30 \%$ sebanyak $73,5 \mathrm{~g}$ ditambahkan kedalam campuran minyak jarak dan asam stearat, kemudian aduk hingga homogen,Beaker glassdiangkat keluar dari water bath, hal tersebut dilakukan untuk menambahkan etanol $96 \%$ sebanyak 45 g.Gliserin $39 \mathrm{~g}$, $\mathrm{NaCl}$ (Natrium Klorida) 1,5 g, gula pasir 22,5 $\mathrm{g}$, coco-deatanolamida $9 \mathrm{~g}$, dan aquades 19,5 g ditambahkan secara berturut-turut, aduk dengan kecepatan konstan pada suhu bahan $70^{\circ} \mathrm{C}-80^{\circ} \mathrm{C}$ hingga bahan tercampur sempurna dan adonan terlihat transparan. Adonan sabun pada beaker glass didinginkan pada wadah yang berisi air dan tambahkan fragrance oil green tea 2 tetes kedalam adonan sebagai pewangi.Adonan sabun perlakuan kontrol/tanpa penambahan ekstrak teh putih langsung dituang kedalam cetakan 
silikon. Adonan sabun perlakuan penambahan ekstrak teh putih didinginkan dahulu hingga suhu mencapai $55^{\circ} \mathrm{C}-60^{\circ} \mathrm{C}$ saat ditambahkan ekstrak teh putih sesuai perlakuan dan aduk hingga tercampur rata, kemudian tuang kedalam cetakan silicon.Busa sabun yang ikut tertuang dalam cetakan dibersihkan secara manual agar tidak menutupi permukaan sabun sesudah mengeras. Adonan sabun pada cetakan silikon didiamkan hingga mengeras pada temperatur kamar dengan ditutupi plastik wrap selama 24 jam.Plastik wrap yang menutupi cetakan silikon dilepas, dan dibiarkan selama 2 - 3 minggu untuk proses curing.

\section{Pengujian Mutu}

Pengujian mutu sabun transparan meliputi: uji sifat fisikokimia, uji aktivitas antibakteri dan uji organoleptik.

\subsection{Pengujian Sifat Fisiko-kimia}

Pengujian sifat fisikokimia dilakukan berdasarkan pada pengujian standar mutu sabun mandi SNI 06-3532-1994 meliputi kadar air dan zat menguap, jumlah asam lemak, jumlah alkali bebas, dan kadar fraksi tak tersabunkan, sedangkan nilai $\mathrm{pH}$ dilakukan berdasarkan ASTM B 117295(2001), kekerasan dan stabilitas busa.

\subsection{Pengujian Aktivitas Antibakteri}

Uji aktivitas antibakteri merupakan pengujian yang dilakukan untuk mengetahui daya hambat sabun dengan penambahan ekstrak teh putih 0,5\%, $1 \%$, dan 1,5\% dan sebagai pembanding sabun tanpa penambahan ekstrak teh putih terhadap bakteri Staphylococcus aureusdalam media Muller Hinton Agar. Pengujian aktivitas antibakteri dilakukan dengan metode cakram dengan larutan Mc. Farland 1 setara dengan jumlah bakteri $3 \times 10^{8} \mathrm{CFU} / \mathrm{mL}$

\subsection{Uji Organoleptik}

Pada uji organoleptik ini dilakukan terhadap responden/panelis untuk mengetahui tingkat penerimaan dan kesukaan (hedonic) dalam segi warna, aroma, tranparansi sabun, kekerasan dan banyak busa yang dihasilkan menggunakan indra penglihatan, perasa, dan sentuhan panelis. Jumlah panelis sebanyak 30 orang yang termasuk kedalam panelis kategori agak terlatih.

\section{Pembobotan}

Pembobotan dilakukan untuk dapat menentukan hasil produk terbaik dari beberapa produk dengan berbagai perlakuan. Prosedurnya dengan menentukan nilai kepentingan secara subjektif oleh peneliti yang diukur berdasarkan penilaian kepentingan parameter dalam produk tersebut. Pembobotan pada penelitian ini diterapkan pada hasil uji fisiko kimia, aktivitas antibakteri, dan uji organoleptik. Contoh parameter yang diterapkan pada hasil uji organoleptik adalah warna, aroma, busa, transparansi, dan kekerasan.

Pembobotan :

$$
\begin{aligned}
& \mathrm{B} \quad=\mathrm{NK} /(\text { Total NK) } \\
& \text { (1) } \\
& \text { NB }=N R \times B \\
& \text { (2) } \\
& \text { Keterangan: } \\
& \mathrm{B}=\text { Bobot } \\
& \text { NK = Nilai kepentingan } \\
& \text { NB = Nilai bobot } \\
& \text { NR = Nilai Rangking } \\
& \text { Ranking } 1=4 \\
& \text { Ranking } 2=3 \\
& \text { Ranking } 3=2 \\
& \text { Ranking } 4=1
\end{aligned}
$$

\section{HASIL DAN PEMBAHASAN}

\section{Aplikasi Penambahan Ekstrak Teh Putih dalam Pembuatan Sabun Padat Transparan \\ Penambahan ekstrak teh putih dilakukan} pada proses pembuatan sabun saat adonan sabun sudah tercampur semua dan siap untuk pencetakan tetapi masih dalam keadaan encer. Adonan yang masih encer lebih mudah dalam pencampuran dan pengadukan ekstrak agar penyebaran ekstrak dapat merata dan menyeluruh. Jika diukur dengan suhu adonan sabun saat pencampuran adalah sebesar $55-65^{\circ} \mathrm{C}$. Hal ini disebabkan pada suhu dibawah dari itu adonan sabun sudah dalam keadaan kental sehingga menimbulkan gelembung udara didalam sabun saat pengadukan pencampuran ekstak teh putih. Bahkan adonan dapat mengeras dan kemudian menempel pada wadah adonaon sebelum 
dipindahkan kedalam cetakan sabun sehingga terjadi kehilangan massa (losses weight) sabun.

Adonan sabun padat transparan menggunakan minyak jarak sangat mudah mengeras pada suhu $<55^{\circ} \mathrm{C}$. Hasilnya membuktikan banyak adonan sabun yang menempel pada beaker glass saat penuangan kedalam cetakan silikon. Selanjutnya jika penambahan ekstrak teh putih pada suhu tersebut dikhawatirkan ekstrak teh putih tidak tercampur rata pada adonan sabun. Maka dari itu, sebaiknya pencampuran ekstrak teh putih dan pemindahan adonan sabun kedalam cetakan tidak terlalu lama beda waktunya. Selain itu, penambahan ekstrak yang semakin banyak diduga membuat adonan sabun menjadi lebih cepat mengeras. Hal ini didukung dengan kehilangan massa yang paling besar terjadi pada sampel sabun perlakuan penambahan ekstrak teh putih $1,5 \% \mathrm{~b} / \mathrm{b}(\mathrm{D})$.

\section{Sifat Fisiko-kimia Sabun Padat Transparan}

\section{Kadar Air dan Zat Menguap}

Pengukuran kadar air dan zat menguap pada suatu bahan perlu dilakukan karena air dapat mempengaruhi kualitas dan daya simpan sabun yang dibuat. Banyaknya air yang ditambahkan pada produk sabun mempengaruhi kelarutan sabun dalam air pada saat digunakan.Pemaparan data nilai kadar air dan zat menguap setiap sampel sabun secara grafik tersaji pada Gambar 1.

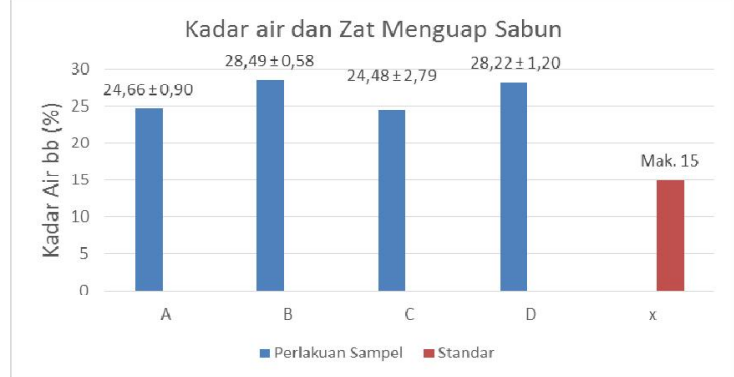

Gambar 1. Grafik Nilai Kadar Air dan Zat Menguap Sabun Padat Transparan pada setiap sampel

Hasil analisis menunjukkan penambahan ekstrak teh putih meningkatan kadar air sabun. Kurva normalitas juga memperlihatkan grafik yang hampir linier mengarah keatas seiring penambahan ekstrak teh putih. Peningkatan nilai kadar air dan zat menguap ini diduga disebabkan oleh ada kandungan pada ekstrak teh putih yang mudah larut oleh air dan konsentrasi ekstrak yang digunakan. Zhen et.al (2002), menjabarkan senyawa - senyawa komposisi teh yang larut terhadap air seperti flavanols, flavanol glukosida, kafein, saponin, dan sebagainya. Kandungan flavanols sendiri merupakan penyusun terbesar pada daun teh sehingga penambahan ekstrak teh putih mempengaruhi kadar air sabun. Selain itu, hidrolisis saponin akan menghasilkan glikon/gula (Wickremasinghe, 1972). Gula yang bersifat higroskopis yang dapat menyerap uap air dari lingkungan sekitar. Kemudian, konsentrasi ekstrak teh putih yang semakin banyak akan meningkatkan jumlah kandungan senyawa-senyawa tersebut sehingga mempengaruhi kadar ari sabun. Namun begitu, sampel sabun $\mathrm{C}$ memiliki nilai kadar air dibawah sampel sabun kontrol. Hal ini diduga pada penambahan ekstrak teh putih sebesar $1 \% \mathrm{~b} / \mathrm{b}$ pada adonan sabun tidak tercampur rata dan banyak ekstrak yang tertinggal pada adonan yang mengeras dalam beaker glass saat pencetakan.

Pada SNI (1994) tentang sabun padat opaque menetapkan nilai maksimal kadar air dan zat menguap pada sabun sebesar $15 \%$. Hasil pengukuran dari penelitian menunjukkan bahwa kadar air dan zat menguap pada setiap sampel uji sabun melewati batas maksimum yang ditetapkan yang berkisar dari $24,48 \%$ hingga 28,49 \%. Spitz (1996) menjelaskan bahwa semakin banyak air yang terkandung membuat sabun semakin mudah menyusut atau habis pada saat digunakan.

\section{Jumlah Asam Lemak}

Kandungan asam lemak menentukan karakteristik sabun yang dihasilkan. Asam lemak diperoleh secara alami melalui hidrolisis trigliserida (William dan Schmitt, 2002). Minyak jarak yang merupakan salah satu bahan utama penyusun sabun membuat karakteristik asam lemak didalamnya semakin jelas. Gambar 2 memaparkan grafik dan data nilai hasil pengujian jumlah asam lemak pada setiap sampel sabun. 


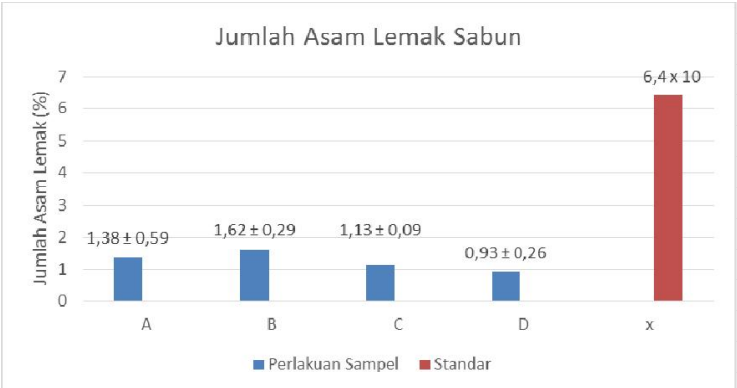

Gambar 2. Grafik Nilai Jumlah Asam Lemak Sabun Padat Transparan pada setiap sampel

Pada Gambar 2 memaparkan perlakuan penambahan ekstrak teh putih membuat kecenderungan penurunan nilai jumlah asam lemak. Grafik yang mengarah kebawah seiring dengan peningkatan penambahan ekstrk teh putih pada kurva normalitas. Hal ini diduga terjadi akibat kandungan ekstrak teh putih dan sifat yang dimiliki senyawa didalamnya membuat minyak/lemak dapat terlarutkan secara sempurna atau berlebihan. Kandungan katekin 13,22 \% b/b dan polifenol $21,54 \% \mathrm{~b} / \mathrm{b}$ pada teh putih yang begitu banyak menurut Hilal dan Engelhardt (2007) tersebut dapat mengikat asam lemak pada sabun. Selain itu, alkaloid pada teh putih merupakan senyawa organik yang dapat memustukan ikatan rangkap minyak lemak dan bersifat basa/alkali (Lenny, 2006). Secara keselurhan, range nilai jumlah asam lemak yang berkisar $0,93 \%$ - 1,62 \% menjadikan semua sampel uji sabun tidak memenuhi standar nilai ketetapan pada SNI (1994) yang tidak mencapai batas minimal jumlah asam lemak yaitu $64 \%$.

\section{Kadar Alkali Bebas}

Reaksi saponifikasi yang sempurna antara asam lemak dan alkali/basa sehingga tidak terdapat sisa/residu setelah reaksi pada pembuatan sabun dapat digolongkan kedalam sabun yang baik. Pada kenyataannya tidak selalu reaksi tersebut berjalan sempurna.

Alkali bebas merupakan alkali yang tidak terikat sebagai senyawa pada saat pembuatan sabun. Hal ini disebabkan karena adanya penambahan alkali yang berlebihan pada saat proses penyabunan. Pada Gambar 3 diperlihatkan rekapitulasi data hasil analisis alkali bebas dalam setiap sampel uji sabun.

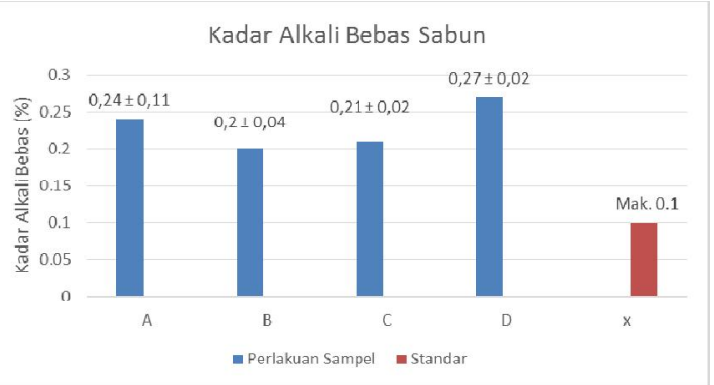

Gambar 3. Grafik Nilai Kadar Alkali Bebas Sabun Padat Transparan pada setiap sampel

Pada Gambar 3 memperlihatkan penambahan ekstrak teh putih membuat nilai kadar asam lemak menjadi meningkat. Hal ini dapat dilihat pada kurva normalitas yang terbentuk mengarah keatas. Teh putih yang mengandung alkaloid didalamnya diduga membuat nilai kadar alkali bertambah karena sifatnya yang basa/alkali (Lenny, 2006). Penambahan ekstrak teh putih yang semakin tinggi membuat kandungan alkaloid dalam sabun juga semakin banyak. Dari hasil yang didapat, seluruh sampel perlakuan penambahan ekstrak teh putih menhasilkan angka yang melebih batas maksimal atau tidak sesuai standar SNI 06-3532-1994 sabun opaque. Kelebihan alkali bebas pada sabun dapat menyebabkan iritasi pada kulit pengguna. Sabun dengan kadar alkali yang lebih besar biasanya digolongkan kedalam sabun cuci.

Kenaikan ini disebabkan $\mathrm{NaOH}$ pada sabun tidak habis bereaksi pada penambahan minyak jarak 60 gr. Selain itu, menurut Wade dan Weller (1994) menyatakan bahwa $\mathrm{NaOH}$ termasuk dalam golongan alkali kuat yang bersifat korosif dan mudah menghancurkan jaringan organik halus.

\section{Kadar Lemak Tak Tersabunkan}

Kadar fraksi tak tersabunkan adalah total keseluruhan senyawa-senyawa terkandung dalam minyak/lemak yang tetap pada bentuk asalnya setelah pembentukan sabun. Adanya fraksi tak tersabunkan dapat menurunkan kemampuan membersihkan (detergensi) pada sabun (Spitz, 1996). Persentase kadar fraksi tak tersabunkan yang didapat dari analisis pengujian setiap sampel sabun dipaparkan dalam Gambar 4. 


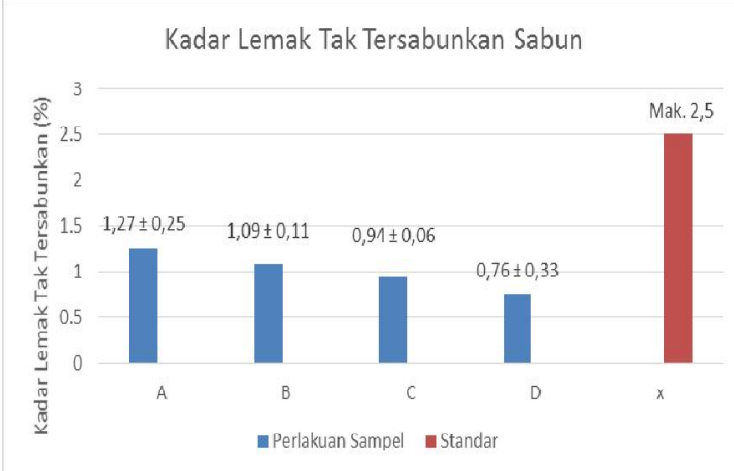

Gambar 4. Grafik Nilai Kadar Lemak Tak Tersabunkan Sabun Padat Transparan pada setiap sampel

Pada Gambar 4 menunjukkan penambahan ekstrak teh putih memiliki kecenderungan menurunkan kadar lemak tak tersabunkan. Hal ini dapat terlihat dari kurva normalitas yang terbentuk hampir linier dengan penambahan ekstrak teh putih. Penambahan ekstrak teh putih yang semakin besar maka semakin kecil nilai kadar lemak tak tersabunkan pada sabun. Penyebab penurunan kadar lemak tak tersabunkan ini diduga disebabkan oleh kandungan katekin, flavanol, alkaloid dan kandungan lain yang sifat basa pada ekstrak teh putih membantu peran alkali $(\mathrm{NaOH})$ untuk mereaksikan minyak/lemak sehingga berproses sempurna. Menurut Hilal dan Engelhardt (2007), pada ekstrak teh putih mengandung katekin sebesar $13,22 \%$ b/b dan flavanol sebesar $21,54 \% \quad b / b$. Kandungan tersebut memberikan pengaruh besar dalam mereaksikan minyak. Selain sifat basanya, kandungan katekin pada teh putih dapat menambah daya bersih pada sabun. Kemampuan daya bersih sabun yang semakin besar ditandai dengan semakin kecilnya nilai kadar lemak tak tersabunkan.

Dalam SNI (1994), nilai kadar lemak tak tersabunkan pada penelitian ini berkisar 0,76 $\%-1,27 \%$, nilai tersebut dapat masuk kedalam 2 kategori yaitu Tipe 1 dan Tipe 2 yang memiliki range nilai $<2,5 \%$. Hal ini dapat diartikan semua sampel uji pada penelitian ini sesuai dengan standar SNI.

\section{Nilai pH}

Cavitch (2001) menjelaskan bahwa derajat keasaman atau $\mathrm{pH}$ adalah mengukur tingkat keasaman dari suatu substansi dalam sebuah larutan.Nilai $\mathrm{pH}$ sabun yang baik menurut ASTM D 1172-95 (2001) berkisar antara 9 - 11. Berikut Gambar 5 yang menunjukkan grafik nilai $\mathrm{pH}$ setiap sampel uji sabun hasil pengukuran menggunakan $\mathrm{pH}$ indikator.

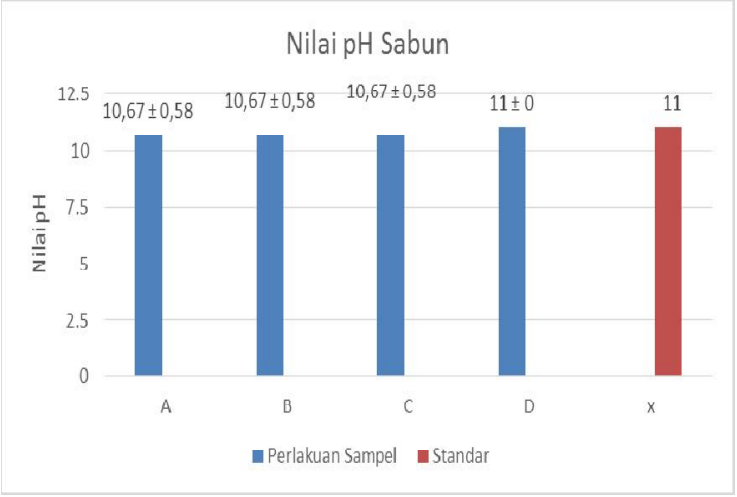

Gambar 5. Grafik Nilai pH Sabun Padat Transparan pada setiap sampel

Pada Gambar 5 memaparkan penambahan ekstrak teh putih tidak meningkatkan nilai pH secara siginifikan. Kenaikan nilai $\mathrm{pH}$ terjadi hanya pada sampel D yang diberikan penambahan ekstrak teh putih sebesar $1,5 \%$ b/b.. Hal ini terlihat dari kurva normalitas nilai $\mathrm{pH}$ yang membentuk hampir linier seiring dengan penambahan ekstrak teh putih. Walaupun begitu, nilai $\mathrm{pH}$ setiap sampel uji sabun pada penelitian ini sesuai dalam standar ASTM D 1172-95 (2001) sehingga dapat dikategorikan sabun yang baik. Peningkatan nilai $\mathrm{pH}$ sabun diduga disebabkan oleh kandungan bahan aktif alkaloid pada ekstrak teh putih yang bersifat basa dapat menjadi salah satu penyebabnya (Lenny, 2006). Selain itu, diduga jumlah kandungan senyawa teh putih sukar larut dengan air seperti lemak, selulosa, lignin, polisakarida, pigmen dan mineral yang sedikit sehingga berpengaruh dalam menurunkan nilai $\mathrm{pH}$. Sifat basa sabun juga dapat disebabkan karena adanya bahan $\mathrm{NaOH}$ yang mengandung ion hidroksida menjadi bahan utama dalam pembuatan sabun. Volume penambahan dan konsentrasi $\mathrm{NaOH}$ yang dipakai juga mempengaruhi peningkatan nilai $\mathrm{pH}$.

\section{Kekerasan}

Kekerasan didefinisikan sebagai karakteristik yang dimiliki oleh benda padat. Pengukuran tingkat kekerasan pada sampel uji sabun dilakukan menggunakan alat yang dinamakan penetrometer. Satuan nilai 
kekersan sabun adalah $\mathrm{mm} / \mathrm{g} / \mathrm{s}$. Kekerasan sampel uji sabun transparan yang dihasilkan dapat dilihat pada Gambar 6.

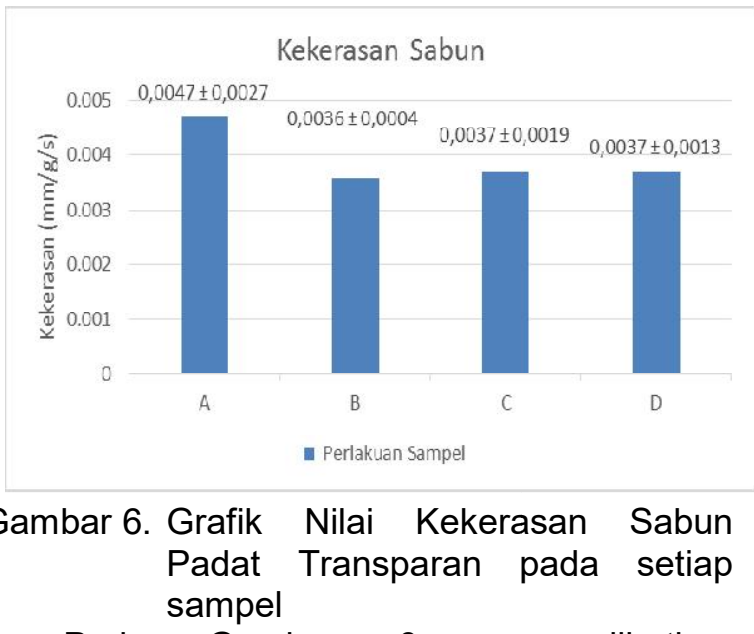

Pada Gambar 6 memperlihatkan penambahan ekstrak teh putih pada pembuatan sabun membuat nilai kekerasannya semakin kecil dibandingkan sampel uji kontrol/tanpa penambahan ekstrak teh putih. Nilai kekerasan sabun yang semakin besar menandakan semakin lunak kekerasan yang dimiliki sabun tersebut. Pada kurva normalitas menunjukkan garis tidak linier pada setiap penambahan ekstrak teh putih menandakan bahwa batas optimum nilai kekerasan tertinggi adalah diantara sampel $A$ dengan $B$ atau pada penambahan $0,5 \% \mathrm{~b} / \mathrm{b}-1 \% \mathrm{~b} / \mathrm{b}$. Penurunan nilai kekerasan dalam sampel uji yang ditambahkan ekstrak teh putih diduga terjadi akibat efek dari berkurangnya penambahan aquades yang digunakan. Pengurangan aquades dalam pembuatan sabun mengurangi kadar air yang terkandung pada sabun sehingga membuat sabun lebih keras. Selain itu kadar air sabun dipengaruhi senyawa aktif seperti flavanols, flavanol glukosida, kafein, saponin pada ekstrak teh putih yang mudah larut oleh air (Zhen et.al., 2002). Sabun yang memiliki nilai kekerasan yang besar menandakan tingkat kekerasan sabun tersebut rendah/lunak. Sabun yang lunak semakin cepat habis saat digunakan karena sabun mudah larut dalam air.

\section{Stabilitas Busa}

Stabilitas busa merupakan konsistensi banyaknya busa yang dihasilkan oleh sabun. Nilai stabilitas busa diperoleh dari ukuran volume busa setelah didiamkan untuk periode waktu tertentu.Grafik nilai stabilitas busa pada setiap sempel uji sabun padat transparan disajikan pada Gambar 7 .

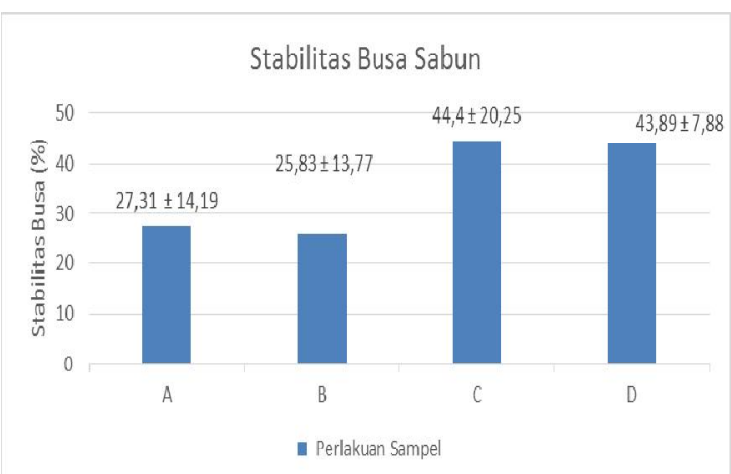

Gambar 7. Grafik Nilai Stabilitas Busa Sabun Padat Transparan pada setiap sampel

Pada Gambar 7 menunjukkan penambahan ekstrak teh putih pada sabun membuat nilai stabilitas busa meningkat. Menurut Martin et.al.,(1993), larutan-larutan yang mengandung bahan-bahan aktif permukaan seperti alkaloid, flavonoid, saponin dan tannin pada ekstrak teh putih menghasilkan busa yang stabil bila dicampur dengan air. Namun pada sampel sabun perlakuan penambahan ekstrak $1,5 \% \mathrm{~b} / \mathrm{b}$ (D) terjadi penurunan nilai stabilitas busa. Kurva normalitas yang terbentuk memperlihatkan garis tidak linier dan puncak ideal penambahan ekstrak teh putih berada diantara $1 \% \mathrm{~b} / \mathrm{b}-1,5 \% \mathrm{~b} / \mathrm{b}$ atau pada sampel C dan D. Puncak ideal merupakan titik dimana kemampuan stabilitas busa pada sabun sudah mencapai optimum pada penambahan tersebut. Hal ini diduga disebabkan penambahan air pada pembuatan sabun semakin berkurang akibat penambahan ekstrak teh putih yang semakin banyak. Bahan aktif pada ekstrak teh putih tidak bereaksi sempurna akibat kurangnya jumlah air pada bahan pembuatan sabun. Selain itu, penambahan ekstrak teh putih berbanding lurus dengan jumlah pelarut yang terkandung. Pada pembuatan sabun, pelarut etanol memiliki peranan lain yaitu sebagai antifoaming agent. Antifoaming agent yang diberikan secara berlebihan menurunkan terbentuknya busa yang dihasilkan (Setyoningrum, 2010).

\section{Aktivitas Antibakteri}

Aktivitas antibakteri ditandai dengan adanya zona bening terjadi disekitar paper disk pada cawan petri yang berisi suspensi 
bakteri Staphylococcus aureus. Suspensi bakteri pada penelitian ini setara dengan laruran Mc Farland 1 sebesar $3 \times 10^{8}$ $\mathrm{CFU} / \mathrm{mL}$. Paper/Cakram disk tersebut sebelumnya dicelupkan kedalam larutan yang didapat dari pengenceran setiap sampel uji sabun selama beberapa menit. Zona bening yang terbentuk pada suspensi bakteri didalam cawan petri diukur dengan penggaris/jangka sorong dalam satuan milimeter $(\mathrm{mm})$ yang dinyatakan dalam diameter daya hambat. Hasil diameter daya hambat yang terjadi pada setiap sampel uji sabun tersaji pada Gambar 8.

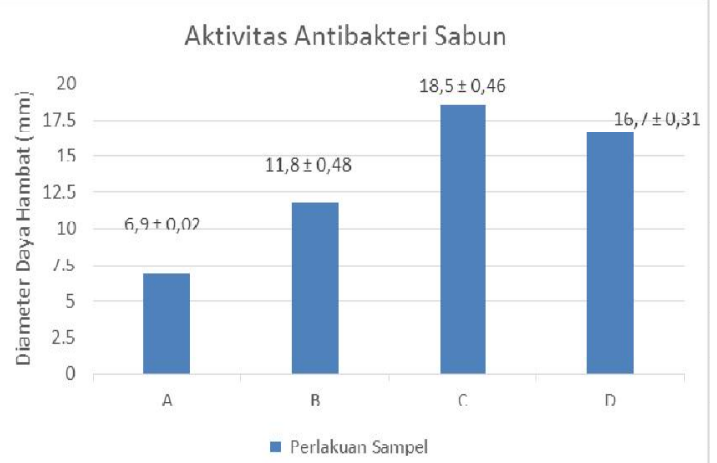

Gambar 8. Aktivitas Antibakteri Sabun Padat Transparan pada setiap sampel

Pada Gambar 8 menunjukan bahwa perlakuan penambahan ekstrak teh putih pada sampel sabun mempengaruhi kemampuan aktivitas antibakteri sabun. Hal ini dibuktikan dengan adanya kenaikan nilai diameter daya hambat pada sabun transparan. Ekstrak teh putih yang mengandung senyawa tannin, gallic acid, dan katekin memiliki sifat bakterisidal diduga membuat diameter daya hambat sabun menjadi lebih besar. Tannin dapat menghambat pertumbuhan bakteri dengan cara mengkoagulasi protoplasma bakteri. Serta senyawa katekin berkerja dengan cara menghancurkan membran sitoplasma sehingga sel bakteri kehilangan metabolisme penting dan kehilangan daya patogenitas, dan dapat mengendapkan protein yang menyebabkan kematian bakteri (Rossi, 2010). Pada bakteri Staphylococcus aureus komponen penyusun dinding sel terdiri dari lapisan peptidoglikan yang tebal, asam teikoat, dan sedikit lipid. Lapisan peptidoglikan dan asam teikoat merupakan polimerlarut dalam air dan bersifat polar, sehingga katekin dan tannin yang terkandung pada ekstrak teh putih mudah menembus lapisan tersebut dibandingakn lapisan lipid (Karlina dkk., 2013).

Akan tetapi, pada Gambar 8 menunjukkan kurva normalitas yang tidak linier akibat terjadinya penurunan diameter daya hambat bakteri sampel sabun $D$ sebesar $16,7 \mathrm{~mm}$ dari sampel sebelumnya (C) sebesar $18,5 \mathrm{~mm}$. Hal tersebut diduga pada penambahan ekstrak teh putih sebesar $1 \% \mathrm{~b} / \mathrm{v}$ pada sabun, kemampuan aktivitas antibakteri telah mencapai batas optimum dalam menghambat pertumbuhan bakteri. Penurunan nilai diameter daya hambat diduga disebabkan oleh bakteri yang mengalami inaktiviasi metabolik yaitu resistensi non genetik (Ganiswarna, 2003). Resistensi non genetik ini terjadi karena bakteri Staphylococcus aureus mengalami adaptasi terhadap antibakteri sabun sehingga menjadi resisten atau sulit menembus lapisan dinding pada penambahan ekstrak teh putih sebesar $1,5 \mathrm{~b} / \mathrm{v}$. Selain itu, menurut Widyasanti (2015) memaparkan penurunan diameter daya hambat pada penambahan ekstrak teh putih diakibatkan perbedaan kecepatan difusi senyawa antibakteri pada media agar serta kepekaan bakteri yang berbeda.

Davis dan Stout (1971), membagi kategori kemapuan aktivitas antibakteri berdasarkan diameter daya hambat pada sabun. Sabun tanpa penambahan ekstrak teh putih termasuk kedalam kategori "Sedang", sedangkan ketika sampel sabundiberikan penambahan ekstrak menjadikan kategori kedalam status "Kuat" karena berkisar antara $10-20 \mathrm{~mm}$. Pada umumnya penambahan ekstrak teh putih berbanding lurus dengan besarnya diameter daya hambat pada bakteri. Menurut Jawetz et.al.,(2007) bahwa ekstrak teh putih dengan diameter zona hambat yang besar mempunyai aktivitas hambatan dengan merusak membran dan dinding sel bakteri, denaturasi, atau menghambat sintesis protein, menghambat sintesa asam nukleat dan mengubah permeabilitas membran.

\section{Analisis Uji Organoleptik}

Uji organoleptik yang dilakukan dalam penelitian ini adalah uji tingkat penerimaan dan uji hedonik atau kesukaan yang meliputi atribut-atribut sabun seperti warna, kekerasan, banyak busa, transparansi, dan 
aroma. Berikut Tabel 2 memaparkan rekapitulasi penilaian panelis pada uji organoleptik.

Tabel 2. Rekapitulasi Penilaian Uji

Organoleptik

\begin{tabular}{|c|c|c|c|c|}
\hline $\begin{array}{l}\text { Parameter } \\
\text { Uji }\end{array}$ & A & B & C & D \\
\hline Warna & 3,80 & 3,53 & 3,10 & 2,87 \\
\hline Aroma & 3,47 & 3,17 & 3,37 & 3,23 \\
\hline $\begin{array}{l}\text { Kekerasan } \\
\text { (tekstur) }\end{array}$ & 47 & 43 & 53 & 67 \\
\hline $\begin{array}{l}\text { Banyak } \\
\text { Busa }\end{array}$ & 3,57 & 70 & 3,13 & 3,00 \\
\hline Transparansi & 2,3 & 3,3 & 3,4 & 3,7 \\
\hline $\begin{array}{l}\text { Rata-Rata } \pm \\
\text { SD }\end{array}$ & $\begin{array}{l}3,32 \\
\pm \\
0,59\end{array}$ & $\begin{array}{l}3,43 \\
\pm \\
0,20\end{array}$ & $\begin{array}{l}3,32 \\
\pm \\
0,19\end{array}$ & $\begin{array}{l}3,30 \\
\pm \\
0,39\end{array}$ \\
\hline
\end{tabular}

Pada Tabel 2 memperlihatkan penilaian panelis berdasarkan parameter uji organoleptik. Pada parameter warna dan aroma, sampel sabun kontrol (A) memiliki skor tertinggi diantara sampel sabun yang lain dengan nilai 3,80 dan 3,47 . Pesaing sampel sabun kontrol adalah sampel sabun dengan perlakuan penambahan ekstrak tehputih dalam 2 parameter yaitu kekerasan dan transparansi. Sedangkan untuk parameter banyak busa, panelis lebih banyak menyukai sampel sabun perlakuan penambahan ekstrak teh putih $0,5 \% \mathrm{~b} / \mathrm{b}(\mathrm{B})$. Walaupun begitu, jika dirata-ratakan penilaian panelis terhadap semua parameter, sampel sabun B merupakan nilai yang paling tinggisebesar 3,43 .

\section{Penentuan Sabun Padat Transparan Terbaik}

Penentuan sampel sabun padat transparan terbaik ditentukan dengan melakukan pembobotan kepentingan terhadap setiap parameter pada uji sifat fisiko-kimia, aktivitas antibakteri, dan organoleptik. Pembobotan dilakukan dengan memberikan nilai kepentingan pada setiap parameter uji yang diperhitungkan. Nilai kepentingan (NK) ditentukan berdasarkan seberapa pentingnya parameter itu didalam produk sabun.

Nilai ranking (NR) ditentukan berdasarkan pengurutan hasil analisis pengujian yang memiliki selisih nilai paling dekat dengan standar yang ada atau berdasarkan kualitas sabun. Kemudian nilai bobot (NB) didapat dari hasil nilai rangking dikalikan dengan bobot setiap peubah (B).
Seluruh nilai bobot setiap parameter pada masing-masing sampel diakumulasikan sehingga diperoleh nilai total bobot. Sampel sabun dengan nilai total bobot terbesar merupakan perlakuan terbaik.

Pada Tabel 3 menunjukkan sampel sabun dengan perlakuan penambahan ekstrak teh putih $1 \%$ b/v (C) merupakan sampel sabun terbaik dari proses pembobotan dalam segi uji sifat fisiko-kimia dan aktivitas antibakteri. Hal tersebut dapat dilihat dari besarnya nilai bobot total dibandingkan dengan sampel sabun lainnya yang mencapai 3,39 .

Sedangkan pada Tabel 4 menunjukkan sampel sabun terbaik menurut hasil pembobotan uji organoleptik adalah sampel sabun kontrol/tanpa penambahan ekstrak (A). Nilai bobot total pada sampel sabun A sebesar 2,75 merupakan nilai terbesar diantara sampel sabun yang lainnya.

\section{KESIMPULAN}

Proses pembuatan sabun padat transparan dilakukan dengan metode hot process dengan suhu pemanasan $80{ }^{\circ} \mathrm{C}$ pada waterbath, kemudian penambahan ekstrak teh putih dilakukan saat suhu adonan mencapai $55^{\circ} \mathrm{C}-60{ }^{\circ} \mathrm{C}$.Sampel sabun $\mathrm{C}$ (perlakuan penambahan ekstrak teh putih 1 $\% \mathrm{~b} / \mathrm{v}$ ) adalah sampel sabun terbaik dalam pengujian sifat fisiko-kimia dan aktivitas antiibakteri berdasarkan perhitungan pembobotan semua parameter. Sifat kimia sabun yang belum sesuai dengan SNI 063532-1994 yaitu kadar air dan zat menguap, jumlah asam lemak dan kadar alkali bebas.Sampel sabun A (perlakuan kontrol/tanpa penambahan ekstrak teh putih) merupakan sabun terbaik dalam pengujian organoleptik dari hasil pembobotan setiap parameternya.

\section{DAFTAR PUSTAKA}

Apriyantono, A. 2001. Tinjauan Krisis Status Kehalalan Alkohol (Etanol). Available at: www.indohalal.com. Diakses pada tanggal 28 Juni 2017.

ASTM Standards. 2001. Designation: D 172 - 92. Standard Guide for $\mathrm{pH}$ of Aqueous Solutions of Soap and Detergents. United States : West Conshocken, PA. 
Badan Pusat Statistik, 2009. Data Konsumsi, Produksi, Ekspor, dan Impor Sabun Mandi Padat di Indonesia. Jakarta.

Cavitch, SM. 2001. Choosing Yours Oil, Oil Propeties of Fatty Acid.

Davis, W. W., and Stout, T. R. 1971. Disc Plate Methods of Microbiological Antibiotic Assay. Microbiology 22: 659665. USA.

Ganiswarna, S. G. 2003. Farmakologi dan Terapi. Universitas Indonesia, Jakarta.

Hambali, E., Bunasor, Tattit K., Suryani, Ani., Kusumah, Giri Angga. 2005. Aplikasi Dietanolamida dari Asam Laurat Minyak Inti Sawit pada Pembuatan Sabun Transparan. Jurnal Teknik Pertanian Vol. 15 (2), 46-53. Fakultas Teknologi Pertanian; Bogor.

Hilal, Y. and Engelhardt, U.H. (2007). Characterisation of white tea Comparasion to green and black tea. Braunschweig University, Department of Food Chemistry, Braunschweig, Germany.

Jawetz, Melnick, Adelberg. 2007. Microbiologi Kedokteran. Edisi 23. Penerjemah : Geo, F. Brooks, Janet S. Butel, Stephen A. Morse. Jakarta : Buku Kedokteran EGC.

Karlina, C.Y., M. Ibrahim, G. Trimulyono. 2013. Aktivitas antibakteri ekstrak herba krokot (Potulaca oleracea L.) terhadap Staphylococcus aureus dan Escherichia coli. Lentera Bio 2 (1) : 8793.

Lenny, S. 2006. Senyawa Flavonoida, Fenilpropanoida dan Alkaloida [Karya IImiah]. Medan: Universitas Sumatera Utara.

Martin, A., J. Swarbick, dan Cammantara. 1993. Buku Farmasi Fisik Edisi Ketiga. Jilid 2. Terjemahan Jakarta: UI Press.

Preedy, V. R. 2013. Tea in Healty and Disease Preventio. United States of America: Academic Press. Available at: http://book.google.co.id. pada tanggal 20 April 2017.

Rossi, A. 2010. 1001 Teh - dari Asal Usul, Tradisi, Khasiat hingga Racikan Teh, edisi 1. Yogykarta : Andi Offset.

RSNI. 2014. Teh Putih. Bandung : PPTK Gambung.

Setyoningrum, E. N. (2010). Optimasi Formula Sabun Transparan dengan Fase Minyak Virgin Coconut Oil dan Surfaktan Cocoamidopropyl Betaine : Aplikasi Desain Faktorial. [Skripsi]. Yogyakarta. Universitas Sanata Dharma

SNI 06 - 3532 - 1994. Standar Mutu Sabun Mandi. Dewan Standarisasi Nasional, Jakarta.

Spitz, L. 1996. Soap and Detergents, A Theoretical and Practical Review. Illinois : AOCS Press

Wade, A. dan P. J. Weller. 1994. Handbook of Pharmaceutical Excipients, 2nd Edition. The American Pharmaceutical Association. Washington, USA.

Wickremasinghe, R.L., 1972. By-products of Tea, Tea Quarterly. Research Institute, Sri Lanka. 43(3): hal $85-87$.

Widyasanti, A., Hajar, S., Rohdiana, D., 2015. Aktivitas Antibakteri Ekstrak Teh Putih Terhadap Bakteri Gram Positif dan Gram Negatif. Departemen Teknik dan Manajemen Industri Pertanian, Universitas Padjadjaran; Jatinangor.

Williams, D. F. dan Schmitt, W. H. 2002. Kimia dan Teknologi Industri Kosmetika dan Produk-Produk Perawatan Diri. Terjemahan. FATETA, IPB, Bogor.

Winarno, F. G. 1997. Kimia Pangan dan Gizi. PT. Gramedia, Jakarta.

Zhen, Y. Y., Libotte, T., Munck, M., Noegel, A. A. and Korenbaum, E. (2002). NUANCE, a giant protein connecting the nucleus and actin cytoskeleton. J. Cell Sci. 115, 3207-3222. 
Tabel 3. Pembobotan Hasil Uji Sifat Fisiko-Kimia dan Aktivitas Antibakteri

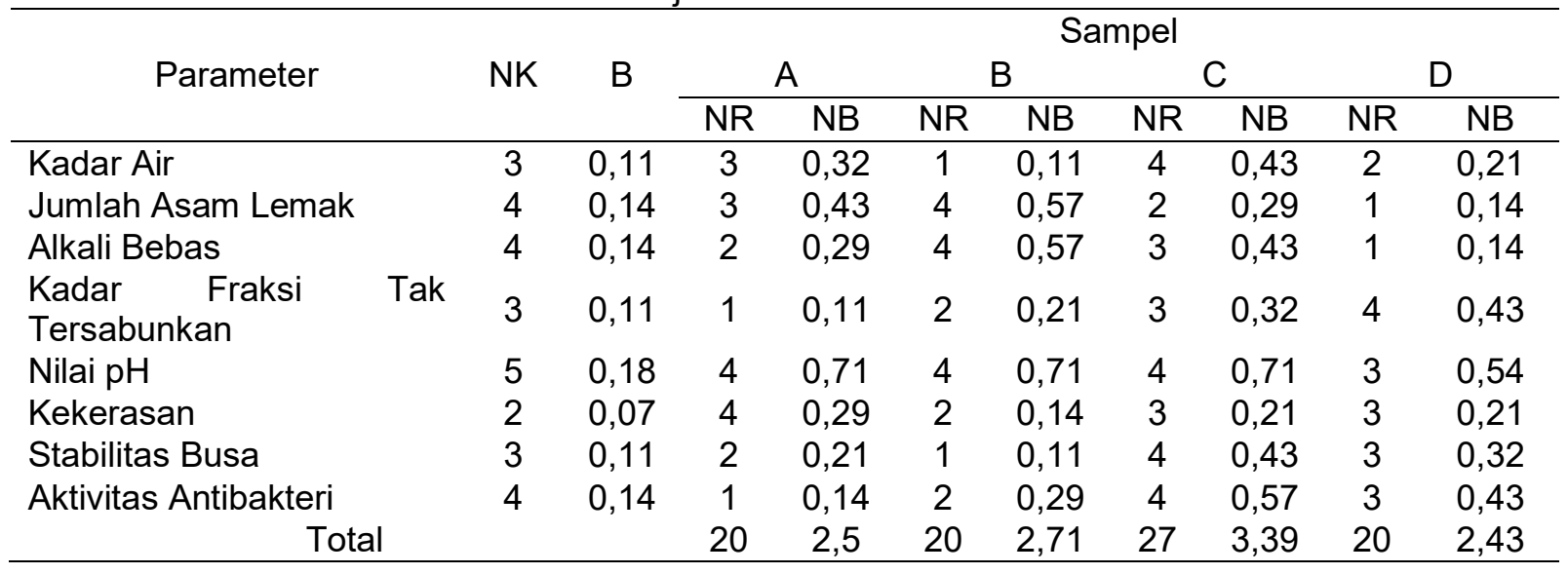

Keterangan: =hasil uji sifat fisiko-kimia dan aktivitas antibakteri dengan nilai terbaik Keterangan: =hasil uji sifat organoleptik dengan nilai terbaik

Tabel 4. Pembobotan Hasil Uji Organoleptik

\begin{tabular}{|c|c|c|c|c|c|c|c|c|c|c|}
\hline \multirow{3}{*}{ Parameter } & \multirow{3}{*}{ NK } & \multirow{3}{*}{ B } & \multicolumn{8}{|c|}{ Sampel } \\
\hline & & & \multicolumn{2}{|c|}{ A } & \multicolumn{2}{|c|}{ B } & \multicolumn{2}{|c|}{ C } & \multicolumn{2}{|c|}{ D } \\
\hline & & & NR & NB & NR & NB & NR & NB & NR & NB \\
\hline Warna & 5 & 0,25 & 4 & 1 & 3 & 0,75 & 2 & 0,5 & 1 & 0,25 \\
\hline Kekerasan & 2 & 0,1 & 4 & 0,4 & 1 & 0,1 & 3 & 0,3 & 2 & 0,2 \\
\hline Busa & 4 & 0,2 & 2 & 0,4 & 1 & 0,2 & 3 & 0,6 & 4 & 0,8 \\
\hline Transparansi & 5 & 0,25 & 3 & 0,75 & 4 & 1 & 2 & 0,5 & 1 & 0,25 \\
\hline Aroma & 4 & 0,2 & 1 & 0,2 & 2 & 0,4 & 3 & 0,6 & 4 & 0,8 \\
\hline Total & & & 14 & 2,75 & 11 & 2,45 & 13 & 2,5 & 12 & 2,3 \\
\hline
\end{tabular}

